\title{
Morphological modifications in soybean in response to soil water management
}

\author{
Clebson Gomes Gonçalves ${ }^{1} \cdot$ Antonio Carlos da Silva Junior $^{1}$ • \\ Maria Renata Rocha Pereira ${ }^{2} \cdot$ Eduardo Custódio Gasparino $^{3} \cdot$ Dagoberto Martins $^{1}$
}

Received: 5 March 2017 / Accepted: 29 May 2017 / Published online: 1 June 2017

(C) Springer Science+Business Media Dordrecht 2017

\begin{abstract}
Water shortage is the most limiting abiotic stress for agricultural crops, and the mechanisms through which plants perceive water restriction are highly complex and must be better understood. In order to shed light on the effect of hydric stress over the anatomical characteristics of soybean, this paper aimed to examine the morphological alterations in two soybean cultivars: MG/BR 46 Conquista (non-transgenic) and BRS Valiosa RR (transgenic), via the response to different soil water managements, in two vegetative development stages. The plants were subjected to five soil water hydric management conditions $(\Psi \mathrm{s})$ : -0.03 ; $-0.05 ;-0.07 ;-0.5 ;-1.5 \mathrm{MPa}$, in vegetative development stages V2 and V4. Evaluations were carried out involving
\end{abstract}

Clebson Gomes Gonçalves

goncalvescg.agro@hotmail.com

Antonio Carlos da Silva Junior

acsjr_agro@hotmail.com

Maria Renata Rocha Pereira

mariarenatarp@hotmail.com

Eduardo Custódio Gasparino

ecgasparino@fcav.unesp.br

Dagoberto Martins

dmartins@fcav.unesp.br

1 Depto. de Produção Vegetal, Faculdade de Ciências Agrárias e Veterinárias-FCAV, UNESP-Univ. Estadual Paulista, Prof. Paulo Donato Castellane s/n, Jaboticabal, SP 14884-900, Brazil

2 Fatec-Faculdade de Tecnologia de Capão Bonito, 60, Amantino de Oliveira Ramos, Terras do Imbiruçu, Capão Bonito, SP 18304-755, Brazil

3 Depto. de Biologia Aplicada à Agropecuária, Faculdade de Ciências Agrárias e Veterinárias-FCAV, UNESPUniv. Estadual Paulista, Prof. Paulo Donato Castellane s/n, Jaboticabal, SP 14884-900, Brazil stomatal conductance, leaf area, leaf anatomy measures (width of palisade and spongy parenchyma, length of central vein, adaxial and abaxial width of central vein, length of vascular bundle, width of vascular bundle), and stem diameter. A higher tolerance was observed in BRS Valiosa RR to moderate hydric deficit conditions when they occurred in soybean stage V2. The BRS Valiosa RR cultivar presents a better morphologically and anatomically adaptive response to moderate hydric restrictions of up to $(-0.07 \mathrm{MPa})$ when they occur in the first weeks of plant development.

Keywords Anatomy - Stomatal conductance $\cdot$ Glycine Max . Drought tolerance

\section{Introduction}

Drought is the most limiting and severe abiotic stress for agricultural crops, as it causes significant losses in vegetal production (Costa et al. 2008; Balardin et al. 2011; Silva et al. 2013). Drought triggers an imbalance between water absorption by the root and leaf transpiration, which causes a reduction in plant growth and development (Dogan et al. 2007; Ashraf 2010; Afzal et al. 2014).

Plant responses to hydric stress are highly complex, as the state of water in plants and the hydric potential of leaves are affected, which causes low turgidity pressure in cells (Cabuslay et al. 2002; Chaitanya et al. 2003; Karthikeyan et al. 2007; Jaleel et al. 2008) and triggers a series of physiological adaptations that have detrimental effects, such as: metabolic impairment of photosynthesis, oxidative damage, hormonal alterations, and the accumulation of proteins related to stress, which leads to interruptions in physiological and biochemical processes in 
the cellular and molecular pathways (Galmés et at. 2011, 2013; Afzal et al. 2014).

The main mechanism by which plants perceive water restriction in soil is signaled by stomatal closure, this being the first and immediate response to hydric deficit, regulating the reduction in water losses through phototranspiration. However, stomata closure is the main cause of decreased photosynthesis, due to the reduction in carbon assimilation rates (Flexas et al. 2004; Paiva et al. 2005; Ohashi et al. 2006; Mak et al. 2014).

Modifications in anatomical characteristics in plants under hydric stress, suggesting specific adaptive processes in plants, have been recorded in the literature, and include: modifications in the architecture and a decrease in the number of leaves, a decrease in leaf expansion, an alteration in the xylem/phloem relationship, a reduction in xylem vessel diameters and in parenchyma cell diameters, and an increase in vascular tissue and in the thickness of the cellular wall (Guerfel et al. 2009; Kutlu et al. 2009; Makbul et al. 2011; Polizel et al. 2011).

Soybean (Glycine $\max$ (L.) Merrill) is an oilseed of great economic importance in many countries and occupies the first position in areas of grain production in the world. Moreover, it is a source of proteins for human and animal consumption. For soybean plants, hydric restriction is quite worrying, since this crop has a low efficiency in terms of water use, and in order to be highly productive it requires a large amount of water for good maintenance (Yang et al. 2003).

Considering the current scenario in which greater areas of soybean cultivation are being opened up without the use of irrigation, the risks in the productive process are high due to hydric restrictions, since in harvest and inter-harvest periods the occurrence of prolonged periods of drought, or "Indian summers", have being occurring more and more frequently, being especially common in southern areas of Brazil.

In order to overcome these problems and achieve high agricultural crop performance, studies have focused on selecting individuals with adaptive characteristics for overcoming environmental stresses. The BRS Valiosa RR (transgenic) soybean cultivar is fundamentally derived from the MG/BR-46 Conquista (non-transgenic) cultivar, obtained through crossbreeding. Although these cultivars have considerable genetic similarities, it is possible, with the improvement process for inserting the gene that confers tolerance to glyphosate herbicides to this cultivar, that target protein genes are also activated by hydric stress in soybean. Therefore, this paper aimed to examine the morphological and anatomical alterations in the MG/BR 46 Conquista (non-transgenic) and BRS Valiosa RR (transgenic) soybean cultivars via their response to different soil water managements, in two vegetative development stages.

\section{Materials and methods}

\section{Plants and growth conditions}

Two experiments were conducted in greenhouse conditions, in the Vegetal Production Department of the Faculty of Agrarian and Veterinary Sciences - FCAV/UNESP, Jaboticabal/SP Campus. The average temperature in the periods the experiments were conducted was $24^{\circ} \mathrm{C}\left( \pm 7^{\circ} \mathrm{C}\right)$ and the relative humidity was between 44.6 and $83.8 \%$ and an $11.8 \mathrm{~h}$ average mean photoperiod.

Two soybean cultivars were used in these studies: MG/ BR 46 Conquista (non-transgenic) and BRS Valiosa RR (transgenic) from the EMBRAPA-Soya germplasm bank. The plants were subjected to five soil water hydric management conditions $(\Psi \mathrm{s}):-0.03 ;-0.05 ;-0.07 ;-0.5$; $-1.5 \mathrm{MPa}$ (soil water management of $13,11,10,9$, and $8 \%$, respectively) during a period of 10 days. The water content in the pots was controlled by weighing them daily. When the weight reached the water potential defined for each treatment, the water was replaced until reaching the maximum soil water potential ( $\Psi \mathrm{s})$ : $-0.01 \mathrm{MPa}(14 \%)$.

For the first study the soil water hydric management conditions were initiated when the plant reached the V2 vegetative development stage (first open trefoil) and the second study when the plants reached the V4 vegetative development stage (third open trefoil) described by Fehr and Caviness (1977).

The experiments were installed and conducted in an entirely randomized design, with four repetitions, in a $5 \times 2$ factorial arrangement, with the first factor consisting of the five soil water hydric conditions $(\Psi \mathrm{s}):-0.03 ;-0.05$; $-0.07 ;-0.5 ;-1.5 \mathrm{MPa}$, and the second factor consisting of the two soybean cultivars (non-transgenic and transgenic).

Before seeding, the soil was air dried until reaching a constant humidity of $3 \%$. To obtain the water retention curve, a Richards pressure plate was used (Klar 1984). Based on the results from the retention curve, five soil water hydric management conditions were established.

The experimental plots were composed of plastic pots containing $3 \mathrm{~kg}$ of soil. The soil was classified as Eutrophic Dark Red Latosol. Four seeds were sown per pot and the plantlets were subsequently thinned, leaving only two plants per pot. The soil was previously irrigated until the humidity reached field capacity, in order to guarantee the effectiveness of the germination process and plantlet development. Before installing the experiments, a sample composed of soil was removed for chemical characterization. The chemical analysis of the soil presented: $\mathrm{pH}\left(\mathrm{CaCl}_{2}\right)$ 5.2; M.O. $=17 \mathrm{~g} \mathrm{dm}^{-3}$; $\mathrm{P}=21 \mathrm{mg} \mathrm{dm}^{-3} ; \mathrm{S}=8 \mathrm{mg} \mathrm{dm}^{-3} ; \mathrm{Ca}=16$ mmolc dm $\mathrm{dm}^{-3}$; $\mathrm{Mg}=5$ mmolc $\mathrm{dm}^{-3} ; \quad \mathrm{K}=2.3$ mmolc $\mathrm{dm}^{-3}$; $\mathrm{H}+\mathrm{Al}=24$ mmolc $\mathrm{dm}^{-3} ; \quad$ S.B. $=23.3$ mmolc $\mathrm{dm}^{-3}$; 
$\mathrm{CTC}=47.3 ; \mathrm{V}=49$. Acidity and fertility correction was carried out in accordance with the recommendations for the crop. Before sowing, the seeds were inoculated with strains of Bradyrhizobium japonicum SEMIA 5079 and Bradyrhizobium elkanii SEMIA $5019\left(9 \times 10^{9}\right.$ viable cells $\mathrm{kg}^{-1}$ of seeds) in order to guarantee maximum soybean plant performance.

\section{Stomatal conductance measurements}

After the treatment period, one plant was used to evaluate stomatal conductance (gs). Stomatal conductance (gs) was measured in a pair of completely expanded leaves based on an intermediate plant height between nine and 11 in the morning using a prometer (Leaf Promoter SC - 1; DECAGON DEVICES, USA).

\section{Leaf area measurements}

One plant of each treatment was collected to determine the leaf area $\left(\mathrm{cm}^{2}\right)$. The leaf area $\left(\mathrm{cm}^{2}\right)$ was determined using the direct method, in which leaves were collected and measured automatically, using a leaf area integrator (Licor $3100)$.

\section{Laboratory tests}

The second plant was collected for the leaf and stem anatomy evaluations. Completely expanded leaves were collected, sampled in the middle portion of the leaf limb. The middle portion of the stem between the penultimate and last expanded leaf of the plant apex was also sampled. Immediately after cutting, the samples were set in $\mathrm{FAA}_{50}$, for $48 \mathrm{~h}$, and subsequently stored in 70\% alcohol (Johansen 1940).

The leaf and stem anatomy analyses were carried out at the Vegetal Morphology Laboratory of the DBAA-FCAVUNESP. The leaf samples were dehydrated, in an increasing ethylic series, immersed in TBA $\left(\mathrm{C}_{4} \mathrm{H}_{10} \mathrm{O}\right)$, and kept in TBA + paraffin oil (Johansen 1940). Then the samples were immersed in paraffin and $10 \mu \mathrm{m}$ thick cross sections were carried out in a rotating microtome (Leica RM2065), which were colored with $0.05 \%$ toluidine blue (O'Brien et al. 1964) and placed between glass slides with synthetic Canada balsam. The following leaf anatomy evaluations were carried out: width of palisade and spongy parenchyma $(\mu \mathrm{m})$, length of central vein $(\mu \mathrm{m})$, adaxial and abaxial width of central vein $(\mu \mathrm{m})$, length of vascular bundle $(\mu \mathrm{m})$, width of vascular bundle $(\mu \mathrm{m})$, and stem diameter $(\mu \mathrm{m})$. The evaluations were carried out based on 20 measurements per treatment using a Bel Photonics microscope.

\section{Statistical analysis}

The results were submitted for variance analysis and significance tested for the sources of significant variation from the F test, by applying the Tukey test (5\% significance). The graphs were plotted using the Sigma Plot 10.0 software.

\section{Results and discussion}

It is well known in the literature that the main mechanism through which plants perceive soil water restriction is signaled by stomatal closure. Because this is the first and immediate response to hydric deficit that regulates a reduction in plant water loss, stomatal control must be considered as an adaptation that leads to maintaining hydric status in drought conditions (Cattivelli et al. 2008). It bears mentioning that a reduction in stomatal density can improve drought tolerance (Tripathi et al. 2016). The results found here show that both cultivars studied presented a large reduction in stomatal conductance in response to soil water levels (Fig. 1a, b).

However, it was possible to observe, especially in the V4 phenological stage (Fig. 1b), that the BRS Valiosa RR (transgenic) soybean cultivar obtained a better response to moderate levels of stress of $(-0.05$ and $-0.07 \mathrm{MPa})$, since the reduction in stomatal conductance was lower compared to the MG/BR 46 Conquista (non-transgenic) soybean cultivar. This can be an indication that the transgenic cultivar was not in a stress condition for hydric restriction up until $(-0.07 \mathrm{MPa})$. As for levels of $(-0.5$ and $-1.5 \mathrm{MPa})$, both cultivars were drastically affected.

The literature reports a progressive reduction in plant stomatal conductance in low soil humidity conditions as a response to water losses (Liu et al. 2005; Ribas-Carbo et al. 2005; Flexas et al. 2006a, b; Galmés et al. 2013). However, this condition of stomatal closure is also reported as being the main cause of a decrease in photosynthesis, due to the low $\mathrm{CO}_{2}$ assimilation rates, which limits plant growth (Flexas et al. 2004; Ohashi et al. 2006; Afzal et al. 2014; Mak et al. 2014).

It was shown that water shortage was a limiting factor for growth, since a progressive reduction in leaf area was recorded in the soybean plants studied (Fig. 1c, d). However, when a small hydric reduction occurred in the V2 phenological state, the non-transgenic cultivar presented greater sensitivities to drought, as a moderate lack of water condition $(-0.07 \mathrm{MPa})$ limited leaf area development (Fig. 1c), unlike the transgenic cultivar, which for the same conditions did not present a reduction in leaf area.

Liu et al. (2003) had also already reported a reduction in soybean plant leaf area due to water scarcity, this being a limiting factor for growth, compromising aerial 
Fig. 1 Effect of drought on a, b stomatal conductance $\left(\mathrm{mmol} \mathrm{m} \mathrm{m}^{-2} \mathrm{~s}^{-1}\right)$ and $\mathbf{c}, \mathbf{d}$ leaf area $\left(\mathrm{cm}^{2}\right)$ in non-transgenic and transgenic soybean cultivars at V2 and V4 phenological stages. Means followed by same lowercase letter, do not differ statistically between water managements and means followed by capital letter, differ statistically between cultivars, by Tukey test $(\mathrm{P}<0.05)$
(A)
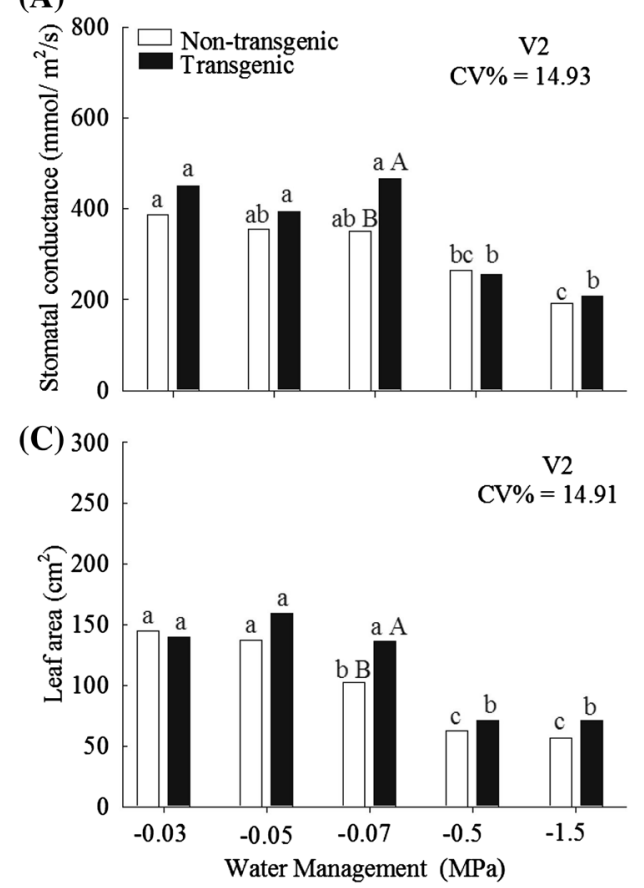

(B)

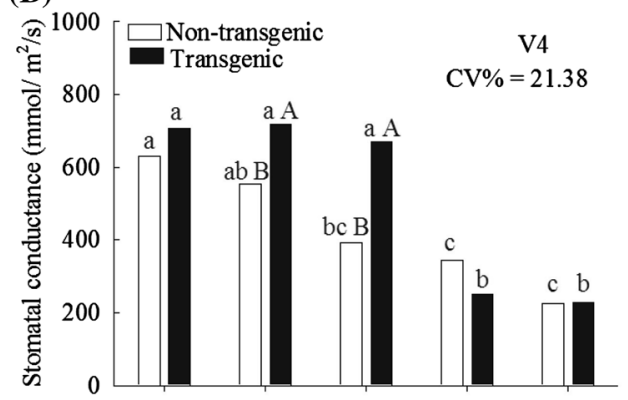

(D)
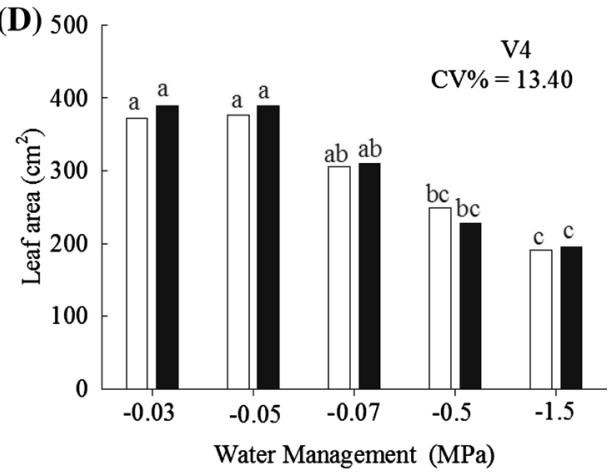

part biomass and productivity (Paiva et al. 2005; Mak et al. 2014). Moreira et al. (2010) reported that under hydric stress conditions, drought tolerant soybean cultivars maintain a greater leaf area compared with less tolerant cultivars.

A modification in leaf thickness was observed in the non-transgenic and transgenic soybean cultivars in stages V2 and V4 when the plants were maintained in hydric restriction conditions. This result was measured by evaluating the thickness of the palisade and spongy parenchyma.

For the V2 stage evaluations it was verified that all of the hydric restriction levels reduced the thickness of the palisade parenchyma for both cultivars studied (Fig. 2a). As for the V4 stage evaluations, the modifications found in the palisade parenchyma for the different soil water managements were barely expressive (Fig. 2b).

The spongy parenchyma also presented a similar response to the palisade parenchyma, since the reduction in the thickness of this was more accentuated in the V2 stage for the different hydric managements in both cultivars (Fig. 3a). In V4 stage, although the plants under hydric stress had been affected, the modifications were smaller.

In general, the non-transgenic cultivar presented a greater leaf thickness in the V2 stage in comparison with the transgenic plants. This result can be observed via the evaluations of the palisade parenchyma and of the spongy parenchyma (Figs. 2c, 3c). However, as the plants developed, this difference was no longer observed, given that no differences were noted between the cultivars in V4 stage for the palisade parenchyma and the spongy parenchyma.
It bears mentioning that as the plant leaf area increased, a reduction occurred in leaf thickness. For both cultivars studied it was possible to observe that in the V4 stage the leaves present less thickness of the palisade parenchyma and of the spongy parenchyma (Figs. 2d, 3d).

Makbul et al. (2011) reported in a study that the palisade and spongy parenchyma is reduced when soybean plants are subjected to hydric deficit conditions. This reduction in leaf lamina is related with a greater quantity of intercellular spaces, which makes it possible for cells to remain more juxtaposed. According to Fahn (1977), in plants with a high photosynthetic capacity, there are few occurrences of intercellular spaces in the mesophyll, which represents an adaptive advantage. According to Polizel et al. (2011), closer cells can represent an adaption in hydric scarcity, since this increases cell contact, which can facilitate the capture of light energy and gaseous elements needed for the photosynthetic process.

The length of the central vein was also drastically affected by hydric stress (Fig. 4a, b). For the evaluations of the central vein in the adaxial surface, a strong reduction was observed for both cultivars in the phenological stages studied (Fig. 5a, b). However, for the V2 phenological stage, a more accentuated linear reduction was recorded with the increase of the stress by the drought (Fig. 5a). A greater central vein width on the adaxial surface was also shown for the BRS Valiosa RR cultivar, compared with MG/BR 46 Conquista for all drought stress conditions (Fig. 5a). 
Fig. 2 Effect of drought on palisade parenchyma $(\mu \mathrm{m})$ in non-transgenic and transgenic soybean cultivars at $V 2$ and $V 4$ phenological stages. Means followed by same lowercase letter, do not differ statistically between water managements and means followed by capital letter, differ statistically between cultivars, by Tukey test $(\mathrm{P}<0.05)$. *Significant by Tukey test $(\mathrm{P}<0.05)$
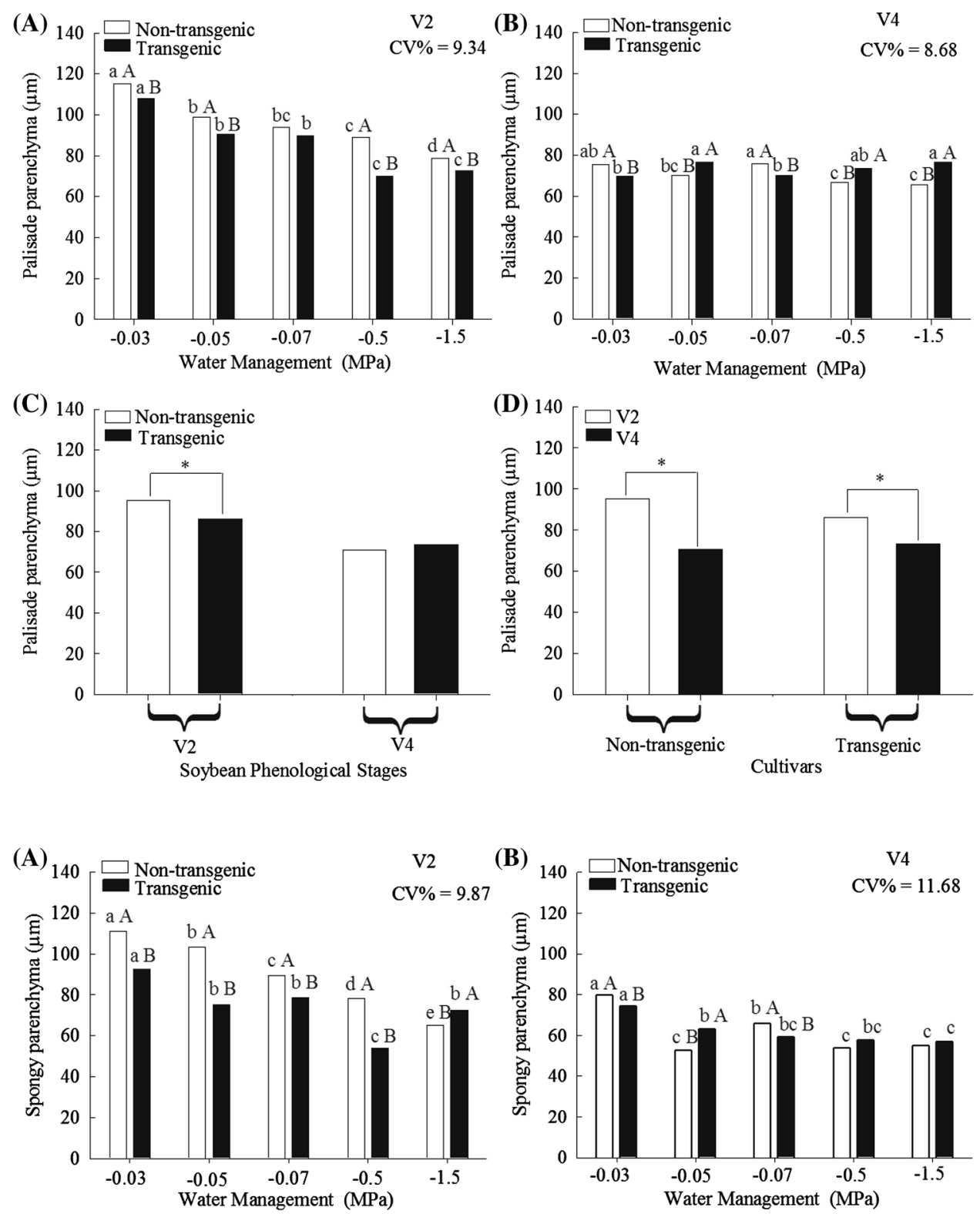

Fig. 3 Effect of drought on spongy parenchyma $(\mu \mathrm{m})$ in non-transgenic and transgenic soybean cultivars at $V 2$ and $V 4$ phenological stages. Means followed by same lowercase letter, do not differ statistically between water managements and means followed by capital letter, differ statistically between cultivars, by Tukey test $(\mathrm{P}<0.05)$. * Significant by Tukey test $(\mathrm{P}<0.05)$

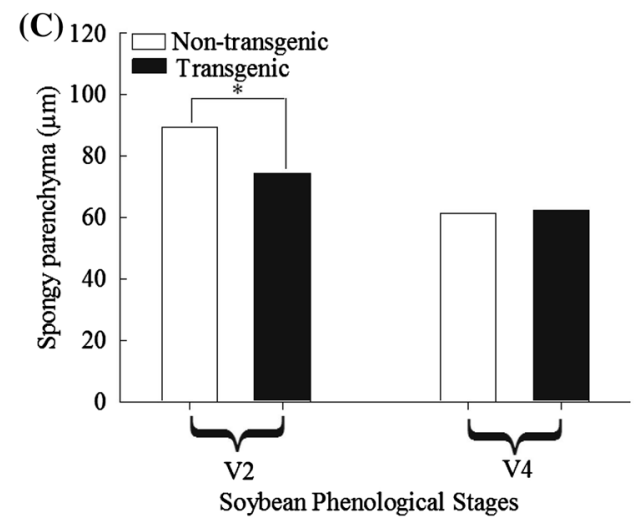

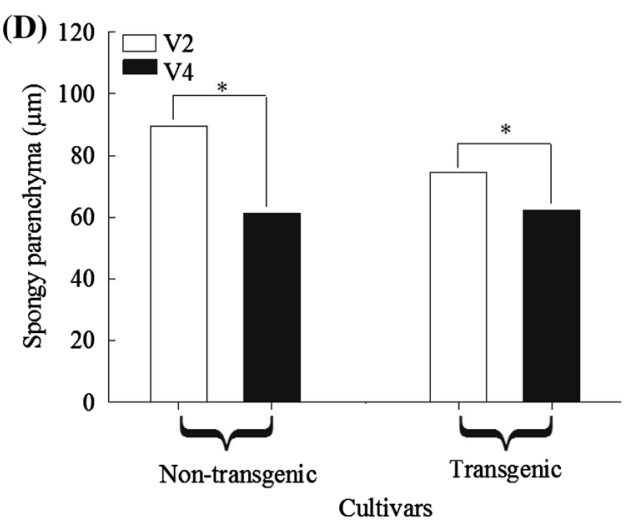

In (Fig. 6d, e) it was verified that the abaxial surface of the non-transgenic cultivar under hydric stresses of $(-0.5$ and $-1.5 \mathrm{MPa})$ in the $\mathrm{V} 2$ phenological stage, and in (Fig. 7e) under hyrdic stresses of $(-1.5 \mathrm{MPa})$ in the V4 phenological stage, presented an intense cell derangement. This was unlike the transgenic cultivar, which although 
Fig. 4 Effect of drought on length of the central vein $(\mu \mathrm{m})$ in non-transgenic and transgenic soybean cultivars at $V 2$ and $V 4$ phenological stages. Means followed by same lowercase letter, do not differ statistically between water managements and means followed by capital letter, differ statistically between cultivars, by Tukey test $(\mathrm{P}<0.05)$

Fig. 5 Effect of drought on central vein width $\mathbf{a}, \mathbf{b}$ adaxial and $\mathbf{c}, \mathbf{d}$ abaxial $(\mu \mathrm{m})$ in nontransgenic and transgenic soybean cultivars at $V 2$ and $V 4$ phenological stages. Means followed by same lowercase letter, do not differ statistically between water managements and means followed by capital letter, differ statistically between cultivars, by Tukey test $(\mathrm{P}<0.05)$
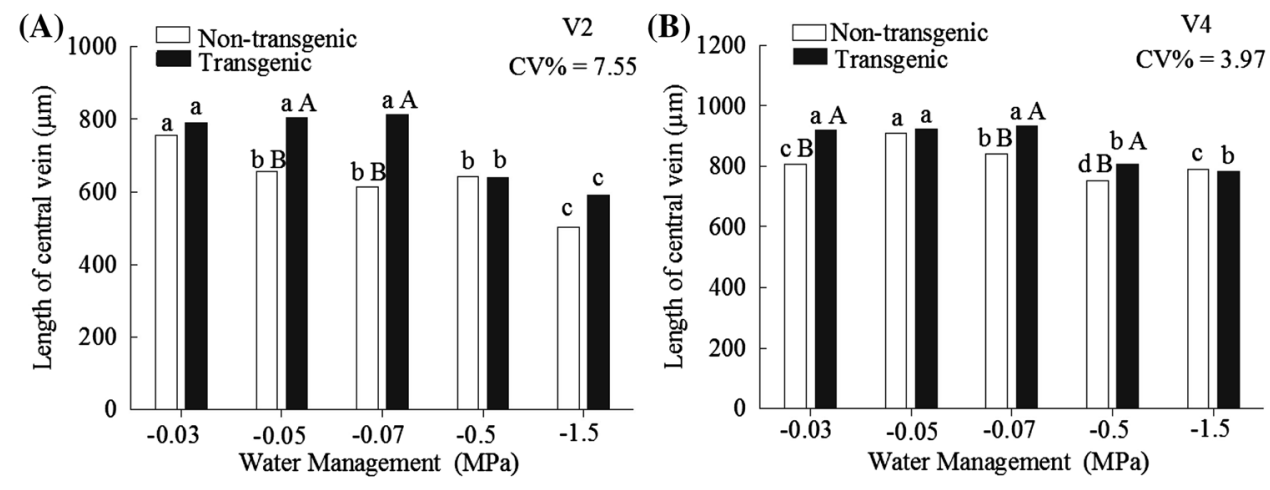

(A)

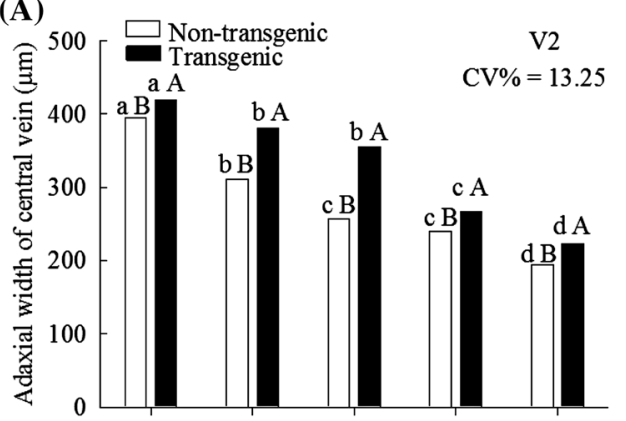

(C)

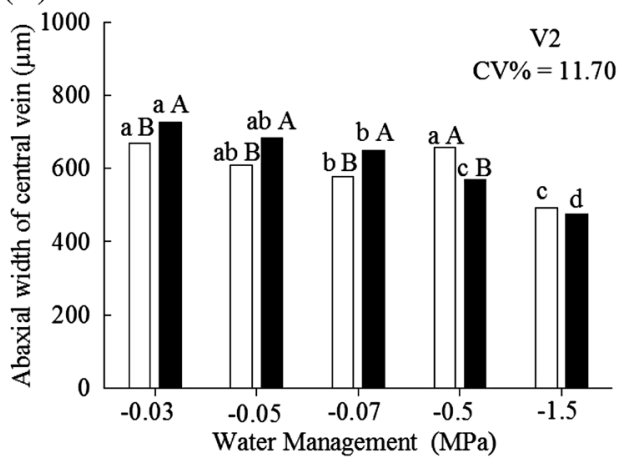

(B)

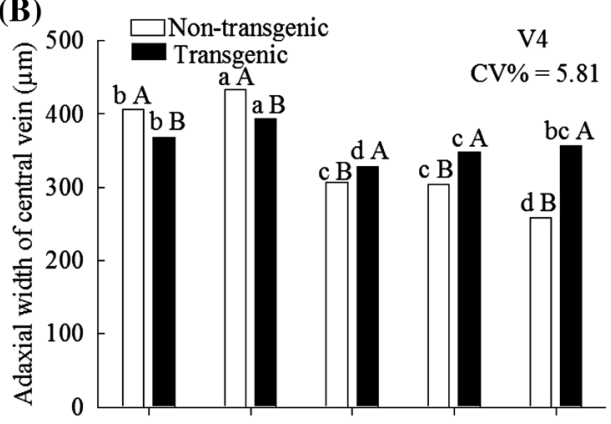

(D)

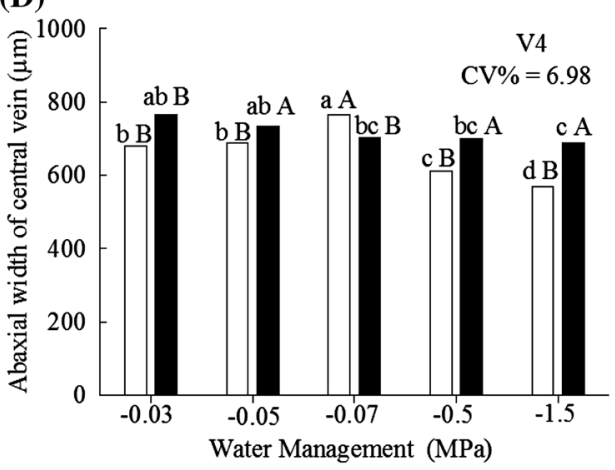

being strongly affected by hydric stress, maintained its natural cell arrangement. This behavior presented by the transgenic cultivar suggests better morphological and anatomical adaptation as a response of the plants in order to tolerate hydric restriction, compared to the non-transgenic cultivar.

In Fig. 8a-d, modifications are also observed in the vascular bundles. Via the length and width of the vascular bundles it was found that in the V2 phenological stage the plants presented a greater adaptive flexibility in response to hydric restriction (Fig. 8a, c). As for hydric stress in the V4 stage, these alterations are less evident (Fig. 8b, d), since the anatomical structure is already established.

It is noted that the vascular bundles of the transgenic cultivar are more evident in V2 stage, compared to the non-transgenic cultivar. In V4 stage, this difference was no longer observed. These results of our study suggest that in V2 stage the transgenic cultivar tissues are already well established, leading to less tissue destructuring in this cultivar when subjected to severe stress $(-0.5$ and $-1.5 \mathrm{MPa})$, unlike the non-transgenic cultivar, in which the tissues were compromised when subjected to these stress conditions.

It bears mentioning that the formation of the tissues that involve the central vein (formed of collenchyma and sclerenchyma and with protective functions) is impaired when the vascular bundles are not well established, which may have lead to higher sensitivity in the non-transgenic plants.

Makbul et al. (2011) reported morphological modifications in the root, stem, and leaf systems in soy plants suffering from hydric deficit. The researchers observed a greater distribution of sclerenchymatic cells in the stem and leaf phloem. It was also observed that the 
Fig. 6 Cross sections of the soybean leaf at the V2 phenological stage, non-transgenic cultivar (a, b, c, d, e), transgenic cultivar (f, $\mathbf{g}, \mathbf{h}, \mathbf{i}, \mathbf{j})$, submitted to different soil water potentials. pp: palisade parenchyma, sp: spongy parenchyma, vb: vascular bundles. Bar: $150 \mu \mathrm{m}$
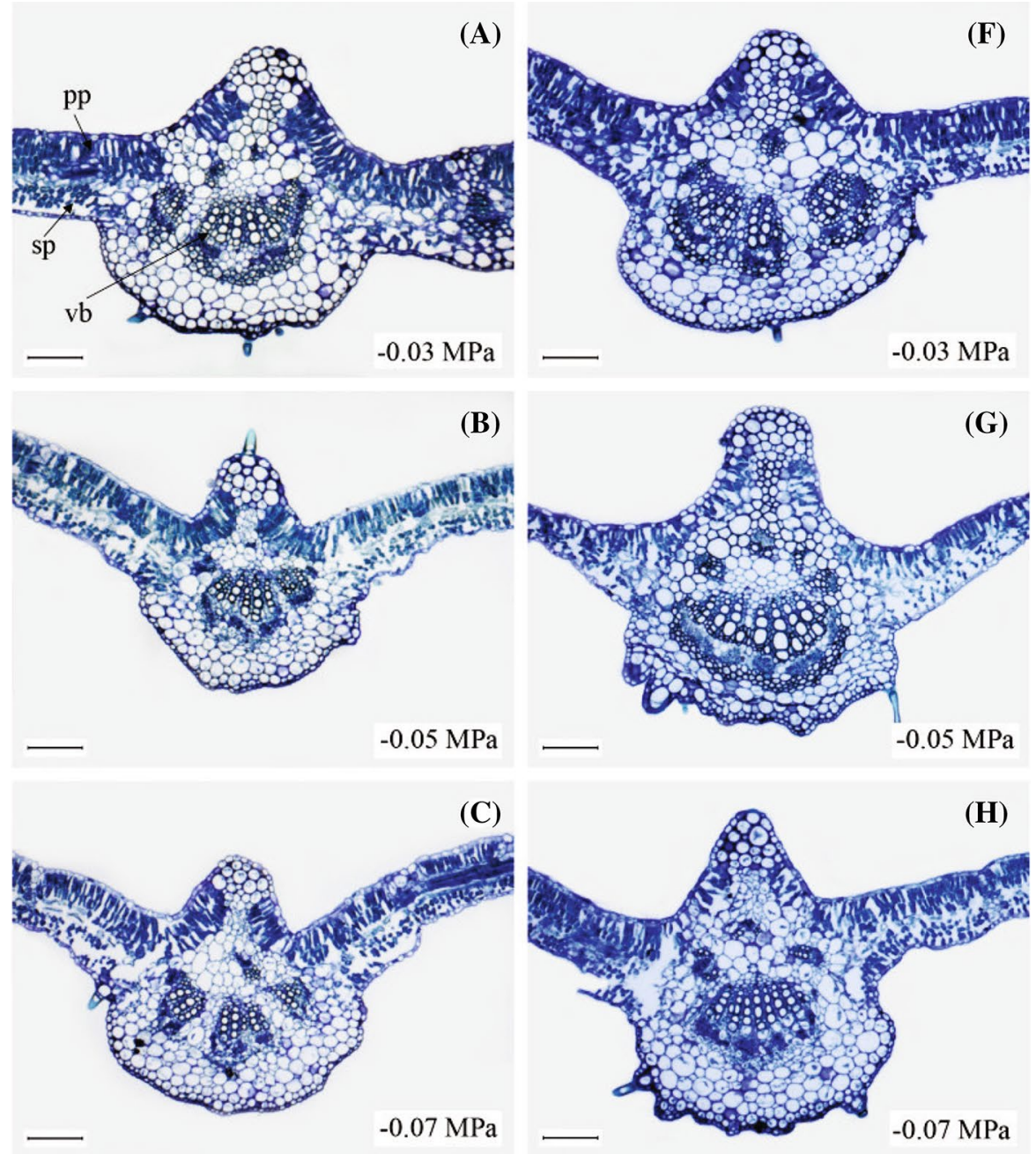

(D)
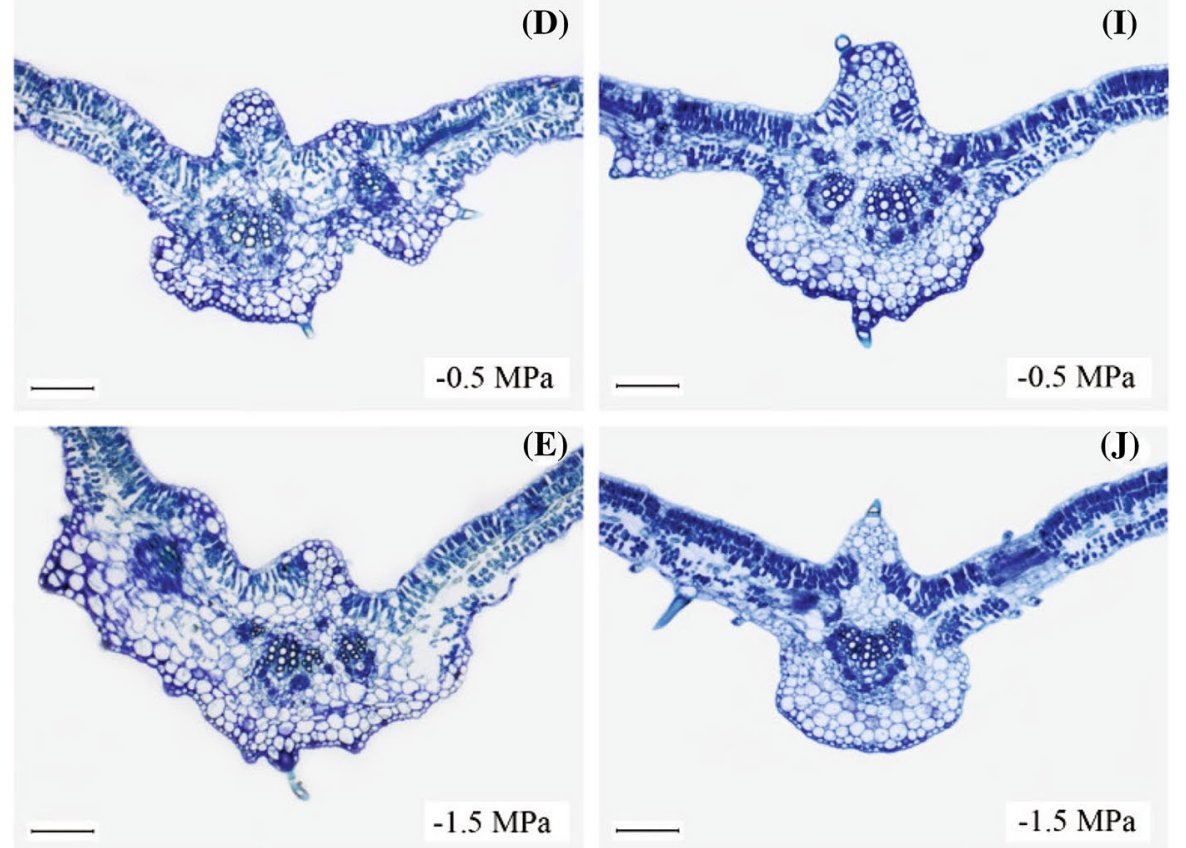
Fig. 7 Cross sections of the soybean leaf at the V4 phenological stage, non-transgenic cultivar (a, b, c, d, e), transgenic cultivar (f, $\mathbf{g}, \mathbf{h}, \mathbf{i}, \mathbf{j})$, submitted to different soil water potentials. pp: palisade parenchyma, sp: spongy parenchyma, vb: vascular bundles. Bar: $150 \mu \mathrm{m}$
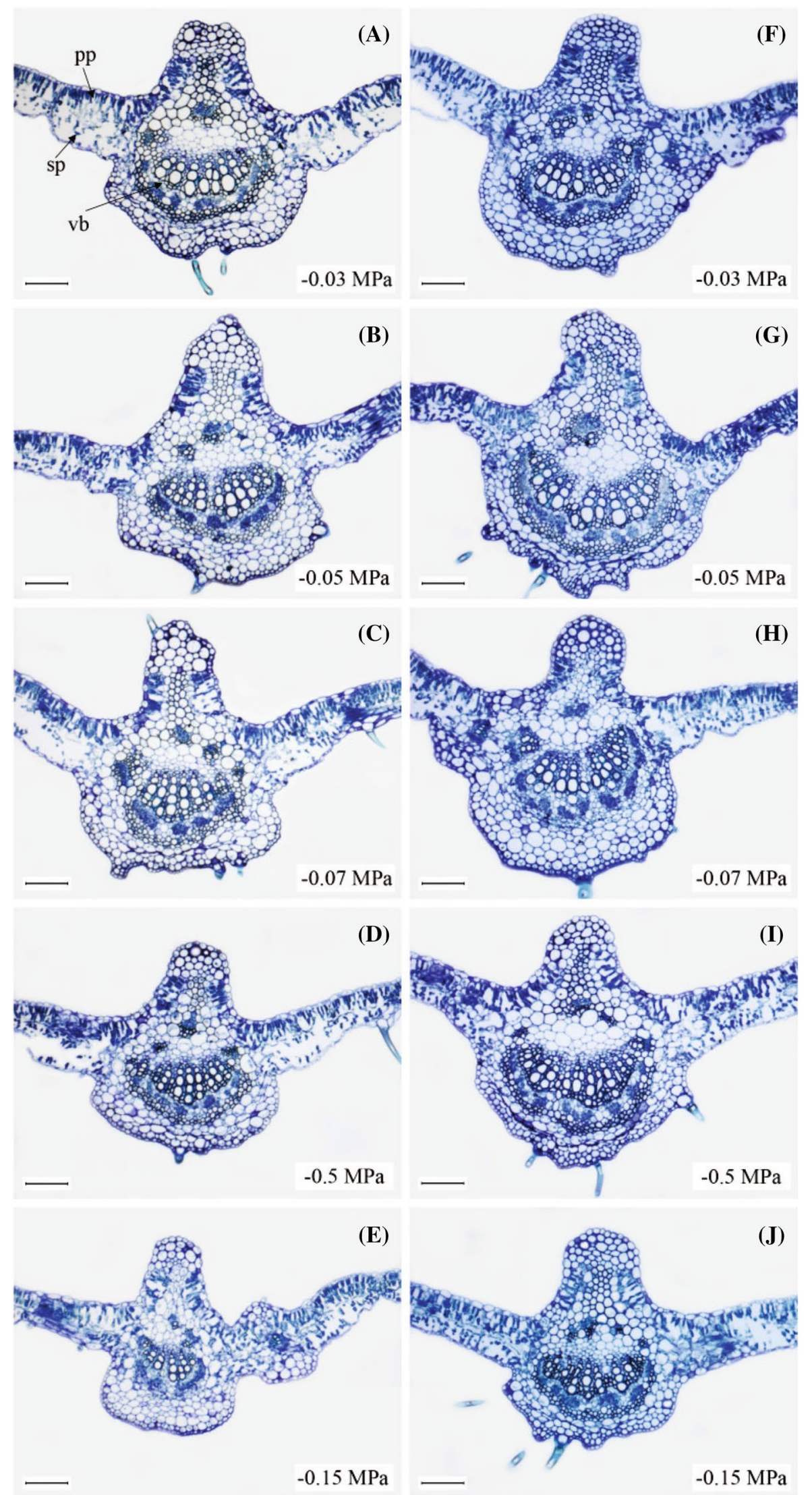
Fig. 8 Effect of drought on length $(\mathbf{a}, \mathbf{b})$ and width $(\mathbf{c}, \mathbf{d})$ of the vascular bundles $(\mu \mathrm{m})$ in non-transgenic and transgenic soybean cultivars at V2 and V4 phenological stages. Means followed by same lowercase letter, do not differ statistically between water managements and means followed by capital letter, differ statistically between cultivars, by Tukey test $(\mathrm{P}<0.05)$
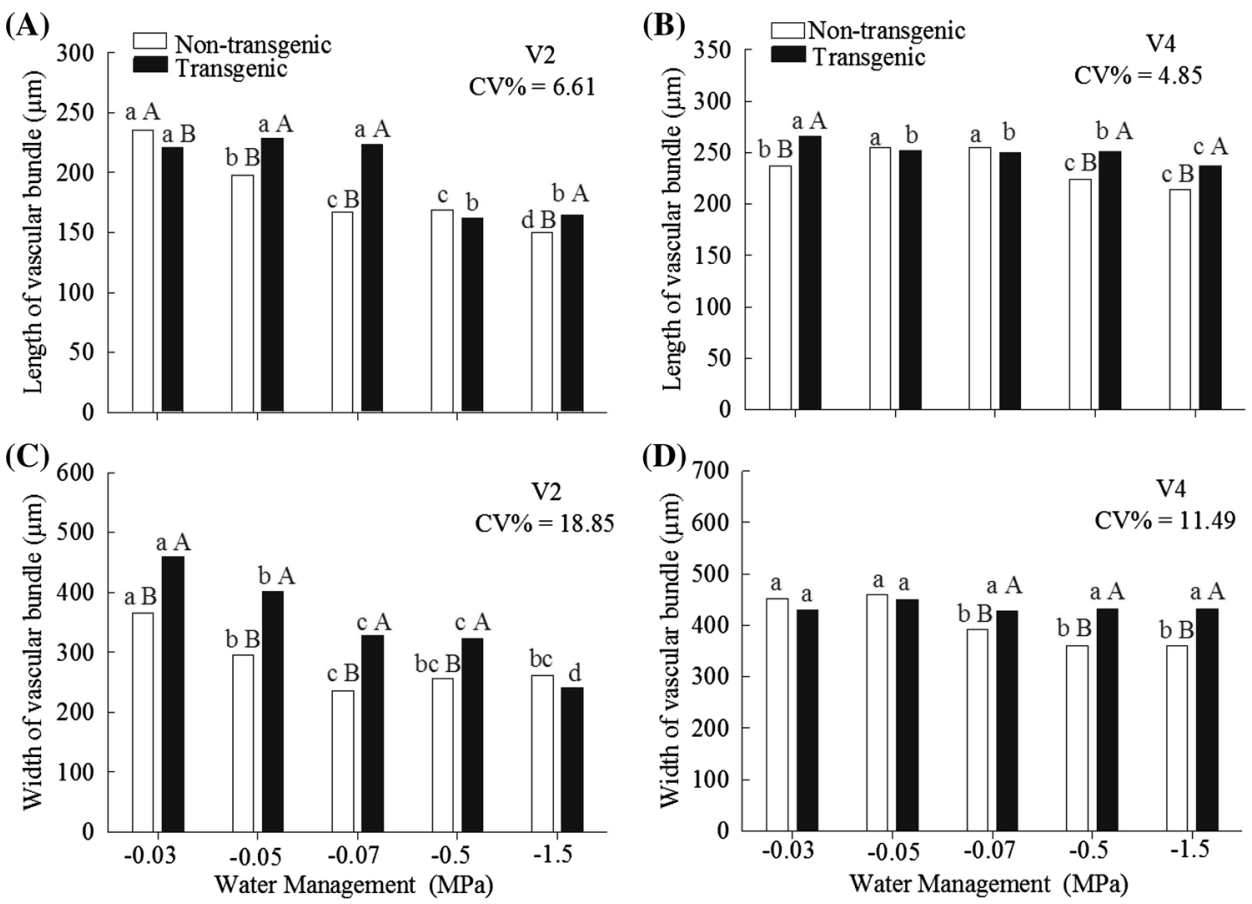

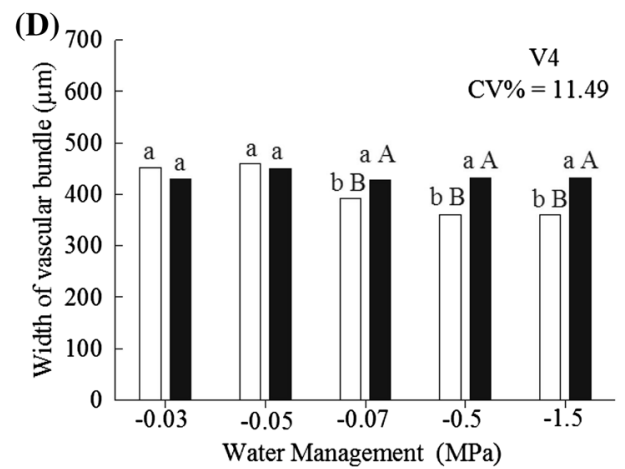

sclerenchyma fibers spread as a continuous layer between the cortex and the phloem in plants suffering from hydric deficit. As for the plants not under stress, the sclerenchyma fibers occur as grouped layers. This sclerenchymatic tissue distribution is of considerable taxonomic value (Canne-Hilliker and Kampny 1991). These results show that the sclerenchya tissue provides a protective adaptive advantage in plants suffering from hydric stress.

As in the leaf anatomy evaluations, a reduction in stem diameter was also observed for both cultivars when kept under hydric stress conditions, in both phenological stages studied (Fig. 9a, b).

There was clearly greater damage to the xylem bundles in the non-transgenic cultivar when subjected to hydric stress of $-1.5 \mathrm{MPa}$, compared to the transgenic cultivar, since they were more compromised (Figs. 10e, j, 11e, j).
Greater fragility in the medullary parenchyma of the stem was observed in the transgenic cultivar, since tissue rupture was recorded in all of the laminas analyzed for the plants kept under hydric stress conditions of $1.5 \mathrm{MPa}$ (Figs. 10j, 11j). As for the non-transgenic cultivar, the medullary tissue was intact. It should also be mentioned that a reduction was observed in cell size for the nontransgenic cultivar when subjected to severe hydric deficit $(-1.5 \mathrm{MPa})$.

It was verified that the in the $\mathrm{V} 4$ phenological stage and under severe hydric deficit conditions, the non-transgenic cultivar presented second meristem rupture, which may have impaired tissue formation (Fig. 11e).

In Figs. 6, 7, 10, and 11, for both the V2 and V4 phenological stages, a reduction was shown in leaf and stem intercellular spaces when the soybean plants were subjected to hydric stress conditions, especially the severe
Fig. 9 Effect of drought on stem diameter $(\mu \mathrm{m})$ in nontransgenic and transgenic soybean cultivars at $V 2$ and $V 4$ phenological stages. Means followed by same lowercase letter, do not differ statistically between water managements and means followed by capital letter, differ statistically between cultivars, by Tukey test $(\mathrm{P}<0.05)$
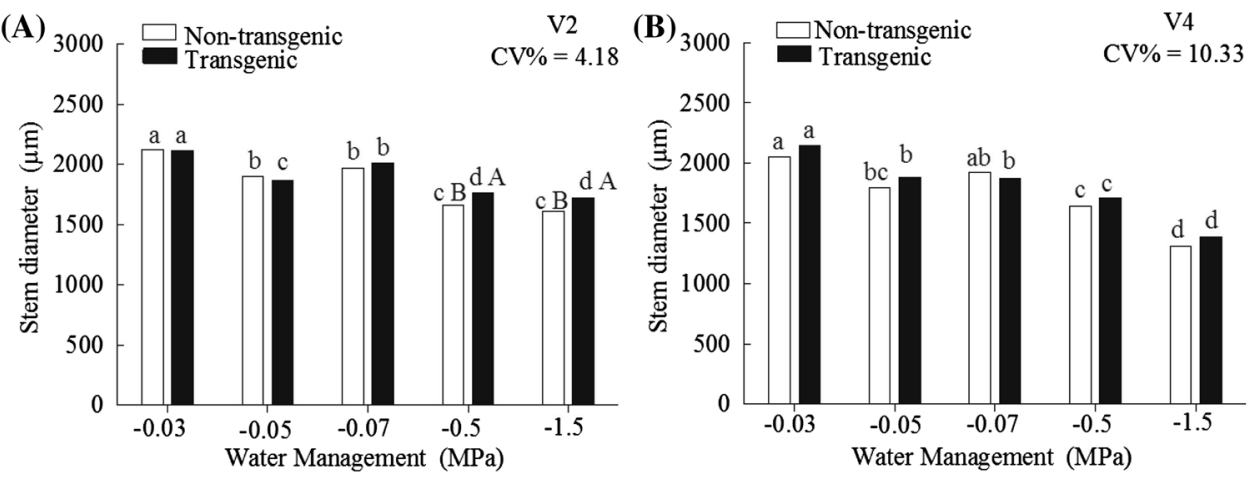
Fig. 10 Cross sections of the soybean stem at the V2 phenological stage, non-transgenic cultivar (a, b, c, d, e), transgenic cultivar (f, $\mathbf{g}, \mathbf{h}, \mathbf{i}, \mathbf{j})$, submitted to different soil water potentials. mp: medullary parenchyma, $\mathrm{xb}$ : xylem bundles. Bar: $110 \mu \mathrm{m}$
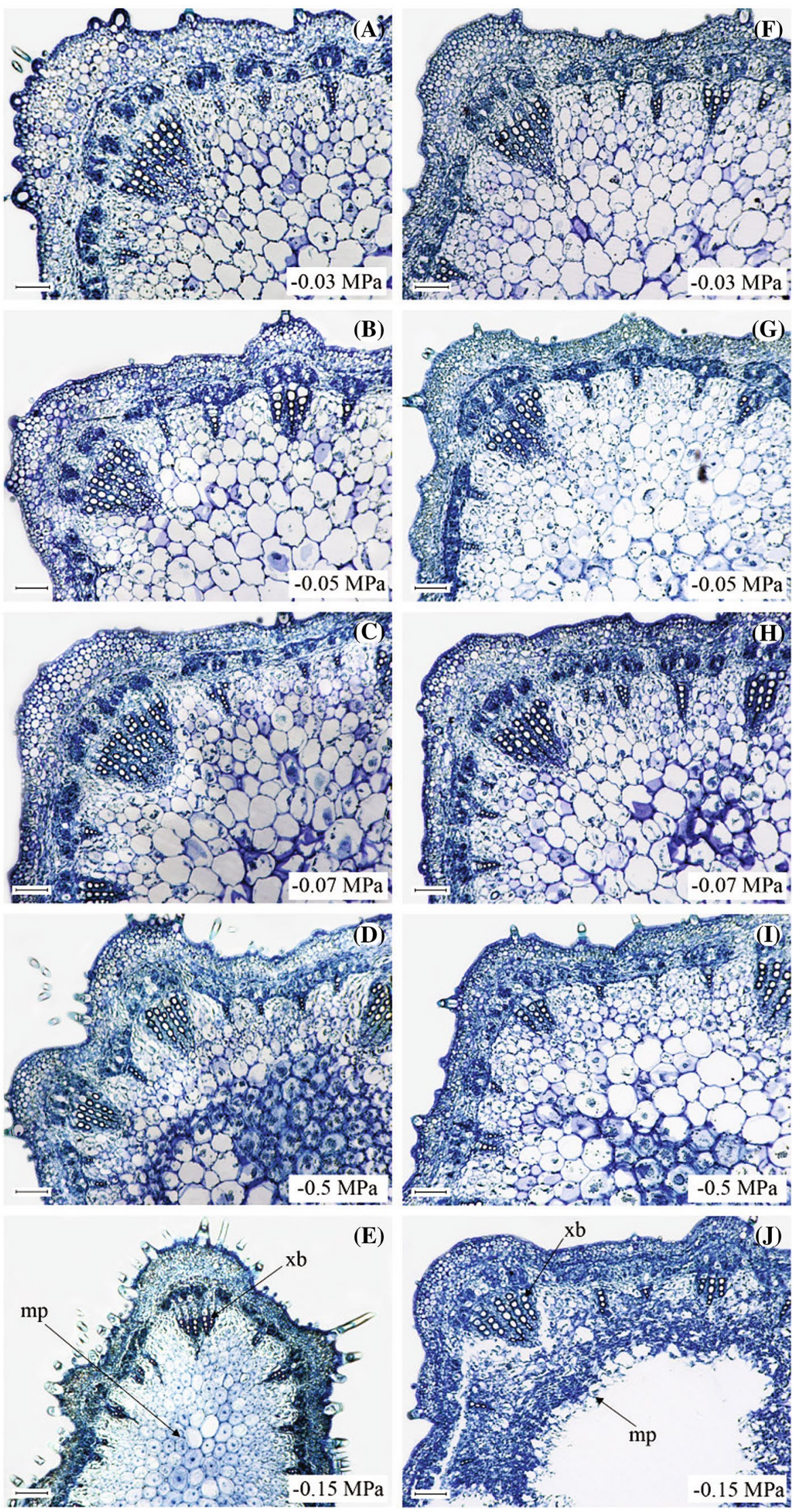
Fig. 11 Cross sections of the soybean stem at the V4 phenological stage, non-transgenic cultivar (a, b, c, d, e), transgenic cultivar (f, $\mathbf{g}, \mathbf{h}, \mathbf{i}, \mathbf{j})$, submitted to different soil water potentials. $\mathrm{mp}$ : medullary parenchyma, $\mathrm{xb}$ : xylem bundles, $\mathrm{r}$ : rupture of the secondary meristem. Bar: $110 \mu \mathrm{m}$
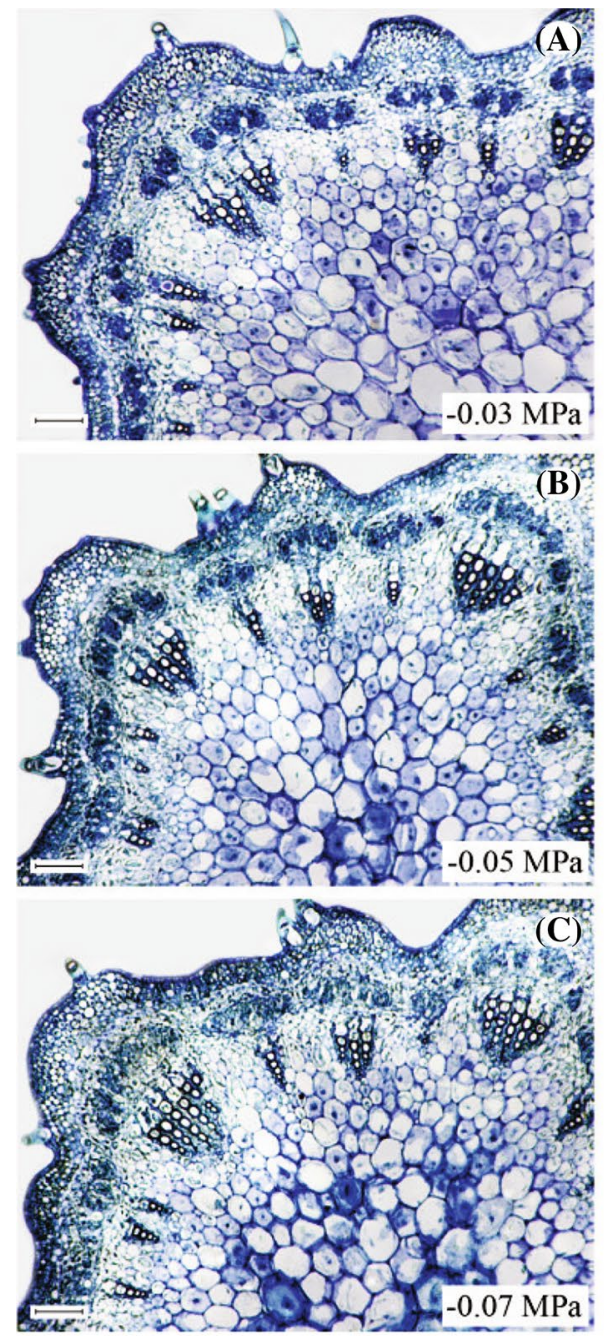

Ci:
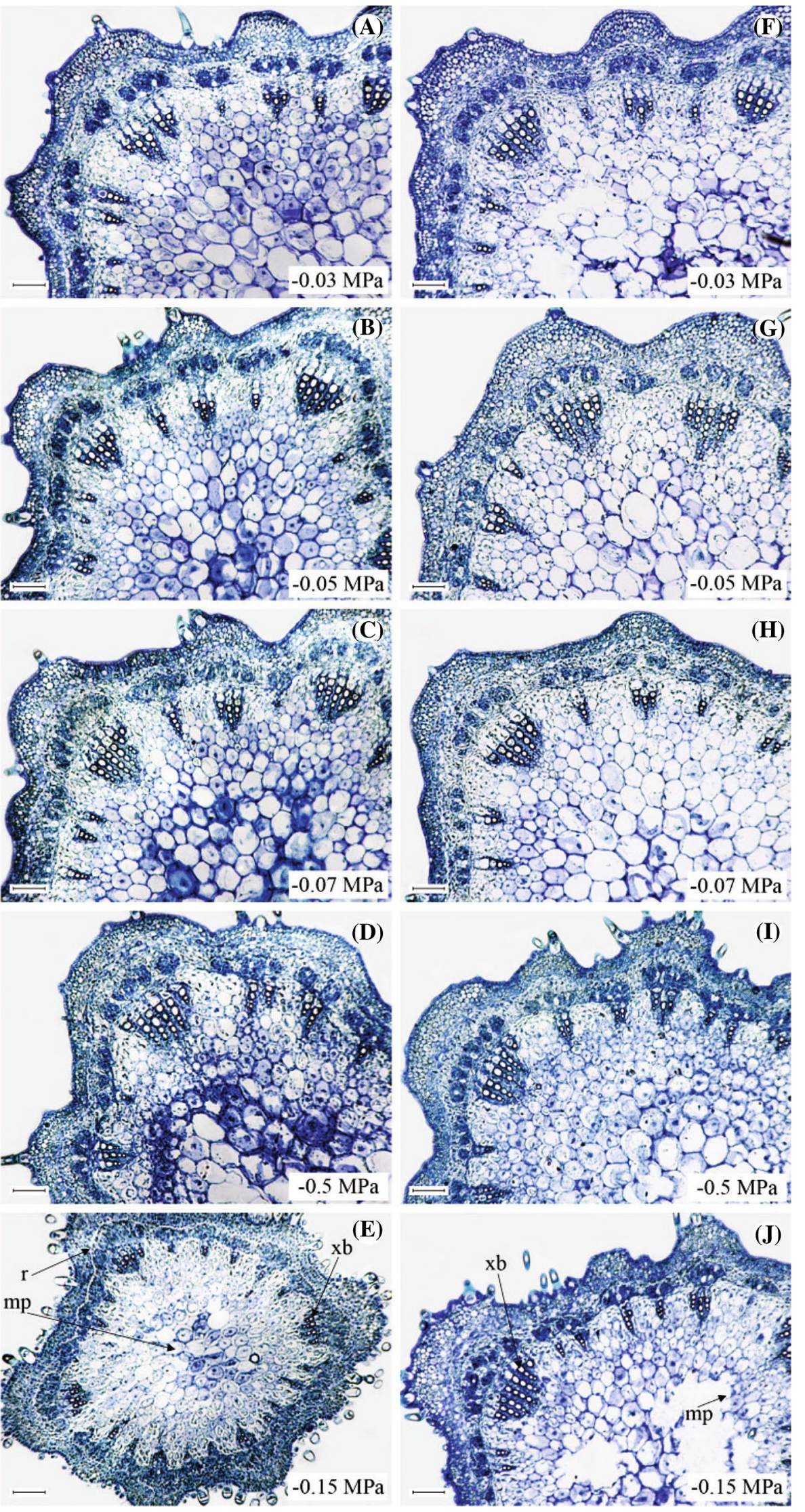
hydric stress condition $(-0.5$ and $-1.5 \mathrm{MPa})$ in V2 stage (Figs. 6, 10), which may be related to greater phenotypic plasticity in soybean plants in response to hydric stress, when this occurs in the initial phenological stage of plant.

This has been measured by various researchers, who have also reported a reduction in cell size and a reduction in intercellur spaces, caused by low turgidity pressure in the cells, due to a reduction in the water content of the tissues of plants suffering from water shortage (Chaitanya et al. 2003; Karthikeyan et al. 2007; Jaleel et al. 2008; Shao et al. 2008).

\section{Conclusions}

All of the anatomical characters evaluated were affected by hydric deficit, with these alterations being more evident in the V2 stage. The results showed greater tolerance in BRS Valiosa RR (transgenic) to moderate hydric deficit conditions when these occur in the initial soybean stage. The BRS Valiosa RR cultivar presents a better morphologically and anatomically adaptive response to moderate hydric deficit of up to $(-0.07 \mathrm{MPa})$ when this occurs in the first weeks of plant development.

Acknowledgements We thank Coordenação de Aperfeiçoamento de Pessoal de Nível Superior (CAPES) for scholarship granted.

\section{References}

Afzal A, Gulzar I, Shahbaz M, Ashraf M (2014) Water deficitinduced regulation of growth, gas exchange, chlorophyll fluorescence, inorganic nutrient accumulation and antioxidative defense mechanism in mungbean [Vignaradiata (L.) Wilczek]. J Appl Bot Food Qual 87:147-156. doi:10.5073/JABFQ.2014.087.022

Ashraf M (2010) Inducing drought tolerance in plants: recent advances. Biotechnol Adv 28:169-183. doi:10.1016/j. biotechadv.2009.11.005

Balardin RS, Silva FD, Debona D, Corte GD, Favera DD, Tormen NR (2011) Seed treatment with fungicides and insecticides reducing the hydric stress on soybean plants. Ciênc Rural 41:1120-1126. doi:10.1590/S0103-84782011000700002

Cabuslay GS, Ito O, Alejar AA (2002) Physiological evaluation of responses of rice (Oryza sativa L.) to water deficit. Plant Sci 163:815-827. doi:10.1016/S0168-9452(02)00217-0

Canne-Hilliker JM, Kampny CM (1991) Taxonomic significance of leaf and stem anatomy of Agalinis (Scrophulariaceae) from the USA and Canada. Can J Bot 69:1935-1950. doi:10.1139/ b91-243

Cattivelli L, Rizza F, Badeck FW, Mazzucotelli E, Mastrangelo AM, Francia E, Marè C, Tondelli A, Stanca AM (2008) Drought tolerance improvement in crop plants: an integrated view from breeding to genomics. Field Crop Res 105:1-14. doi:10.1016/j. fcr.2007.07.004

Chaitanya KV, Jutur PP, Sundar D, Reddy AR (2003) Water stress effects on photosynthesis in different mulberry cultivars. Plant Growth Regul 40:75-80. doi:10.1023/A:1023064328384
Costa RCL, Lobato AKS, Oliveira Neto CF, Maia PSS, Alves GAR, Laughinghouse HD (2008) Biochemical and physiological responses in two Vigna unguiculata (L.) Walp. cultivars under water stress. J Agron 7:98-101. doi:10.3923/ja.2008.98.101

Dogan E, Kirnak H, Copur O (2007) Deficit irrigations during soybean reproductive stages and CROPGRO-soybean simulations under semi-arid climatic conditions. Field Crop Res 103:154159. doi:10.1016/j.fcr.2007.05.009

Fahn A (1977) Plant anatomy. Pergamon, Oxford, p 611

Fehr WR, Caviness CE (1977) Stages of soybean development. Ames: State University of Science and Technology, p. 11 (Specialreport, 80)

Flexas J, Bota J, Loreto F, Cornic G, Sharkey TD (2004) Diffusive and metabolic limitations to photosynthesis under drought and salinity in $\mathrm{C}_{3}$ plants. Plant Biol 6:269-279. doi:10.105 5/s-2004-820867

Flexas J, Bota J, Galmés J, Medrano H, Ribas-Carbó M (2006a) Keeping a positive carbon balance under adverse conditions: responses of photosynthesis and respiration to water stress. Physiol Plant 127:343-352. doi:10.1111/j.1399-3054.2006.00621.x

Flexas J, Ribas-Carbó M, Bota J, Galmés J, Henkle M, MartínezCañellas S, Medrano H (2006b) Decreased Rubisco activity during water stress is not induced by decreased relative water content but related to conditions of low stomatal conductance and chloroplast $\mathrm{CO}_{2}$ concentration. New Phytol 172:73-82. doi:10.1111/j.1469-8137.2006.01794.x

Galmés J, Conesa MA, Ochogavía J, Perdomo JA, Francis DM, Ribas-Carbó M, Savé R, Flexas J, Medrano H, Cifre J (2011) Physiological and morphological adaptations in relation to water use efficiency in Mediterranean accessions of Solanum lycopersicum. Plant Cell Environ 34:245-260. doi:10.1111/j.1365-3040.2010.02239.x

Galmés J, Ochogavía J, Gago J, Roldán EJ, Cifre J, Conesa MÀ (2013) Leaf responses to drought stress in Mediterranean accessions of Solanum lycopersicum: anatomical adaptations in relation to gas exchange parameters. Plant Cell Environ 36:920-935. doi:10.1111/pce.12022

Guerfel M, Baccouri O, Boujnah D, Chaïbi W, Zarrouk M (2009) Impacts of water stress on gas exchange, water relations, chlorophyll content and leaf structure in the two main Tunisian olive (Olea europaea L.) cultivars. Sci Hortic 119:257-263. doi:10.1016/j.scienta.2008.08.006

Jaleel CA, Manivannan P, Lakshmanan GMA, Gomathinayagam M, Panneerselvam R (2008) Alterations in morphological parameters and photosynthetic pigment responses of Catharanthusroseus under soil water deficits. Colloid Surf B Biointerfaces 61:298-303. doi:10.1016/j.colsurfb.2007.09.008

Johansen DA (1940) Plant microtechnique. McGrow-Hill Book, New York, p 523

Karthikeyan B, Jaleel CA, Gopi R, Deiveekasundaram M (2007) Alterations in seedling vigour and antioxidant enzyme activities in Catharanthusroseus under seed priming with native diazotrophs. J Zhejiang Univ Sci B 8:453-457. doi:10.1631/jzus.2007. B0453

Klar AE (1984) Evapotranspiração. In: A água no sistema soloplanta-atmosfera. 2 (ed) Klar AE. Nobel, São Paulo, p 408

Kutlu N, Terzi R, Tekeli Ç, Şenel G, Battal P, Kadioğlu A (2009) Changes in anatomical structure and levels of endogenous phytohormones during leaf rolling in Ctenanthe setosa under drought stress. Turk J Biol 33:115-122. doi:10.3906/biy-0806-6

Liu F, Jensen CR, Andersen MN (2003) Hydraulic and chemical signals in the control of leaf expansion and stomatal conductance in soybean exposed to drought stress. Funct Plant Biol 30:65-73. doi:10.1071/FP02170

Liu F, Andersen MN, Jacobsen SE, Jensen CR (2005) Stomatal control and water use efficiency of soybean (Glycine max L. Merr.) 
during progressive soil drying. Environ Exp Bot 54:33-40. doi:10.1016/j.envexpbot.2004.05.002

Mak M, Babla M, Xu SC, O'Carrigan A, Liu XH, Gong YM, Holford P, Chen ZH (2014) Leaf mesophyll $\mathrm{K}^{+}, \mathrm{H}^{+}$and $\mathrm{Ca}^{2+}$ fluxes are involved in drought-induced decrease in photosynthesis and stomatal closure in soybean. Environ Exp Bot 98:1-12. doi:10.1016/j.envexpbot.2013.10.003

Makbul S, SaruhanGüler N, Durmuş N, Güven S (2011) Changes in anatomical and physiological parameters of soybean under drought stress. Turk J Biol 35:369-377. doi:10.3906/bot-1002-7

Moreira RS, Medri ME, Neumaier N, Lemos NG, Pimenta JÁ, Tobita S, Brogin RL, Guimarães FCM, Oliveira MCN, Farias JRB, Abdelnoor RV, Nepomuceno AL (2010) Soybean physiology and gene expression during drought. Genet Mol Res 9:1946-1956. doi:10.4238/vol9-4gmr851

O'Brien TP, Feder N, McCully ME (1964) Polychromatic staining of plant cell walls by toluidine blue O. Protoplasma 59:368-373. doi:10.1007/BF01248568

Ohashi Y, Nakayama N, Saneoka H, Fujita K (2006) Effects of drought stress on photosynthetic gas exchange, chlorophyll fluorescence and stem diameter of soybean plants. Biol Plant 50:138-141. doi:10.1007/s10535-005-0089-3

Paiva AS, Fernandes EJ, Rodrigues TJ, Turco JE (2005) Stomatal conductance in leaves of bean plants submitted to different irrigation regimes. Eng Agríc 25:161-169. doi:10.1590/ S0100-69162005000100018

Polizel AM, Medri ME, Nakashima K, Yamanaka N, Farias JRB, Oliveira MCN, Marin SRR, Abdelnoor RV,
Marcelino-Guimarães FC, Fuganti R, Rodrigues FA, StolfMoreira R, Beneventi MA, Rolla AAP, Neumaier N, YamaguchiShinozaki K, Carvalho JFC, Nepomuceno AL (2011) Molecular, anatomical and physiological properties of a genetically modified soybean line transformed with rd29A: AtDREB1A for the improvement of drought tolerance. Genet Mol Res 10:36413656. doi:10.4238/2011.October.21.4

Ribas-Carbo M, Taylor NL, Giles L, Busquets S, Finnegan PM, Day DA, Lambers H, Medrano H, Berry JA, Flexas J (2005) Effects of water stress on respiration in soybean leaves. Plant Physiol 139:466-473. doi:10.1104/pp105.065565

Shao HB, Chu LY, Shao MA, Jaleel CA, Hong-Mei M (2008) Higher plant antioxidants and redox signaling under environmental stresses. C R Biol 331:433-441. doi:10.1016/j.crvi.2008.03.011

Silva ARA, Bezerra FML, Lacerda CF, Pereira Filho JV, Freitas CAS (2013) Gas exchange in sunflower plants subjected to water deficit at different stages of growth. Rev Ciênc Agron 44:86-93. doi:10.1590/S1806-66902013000100011

Tripathi P, Rabara RC, Reese RN, Miller MA, Rohila JS, Subramanian S, Shen QJ, Morandi D, Bücking H, Shulaev V, Rushton PJ (2016) A toolbox of genes, proteins, metabolites and promoters for improving drought tolerance in soybean includes the metabolite coumestrol and stomatal development genes. BMC Genom 17:1-22. doi:10.1186/s12864-016-2420-0

Yang PH, Gq Li GL, Wu SJ (2003) Effect of drought stress on plasma membrane permeability of soybean varieties during floweringpodingstage. Agric Res Arid Areas 21:127-130 